\section{The Call for Senate Reform: An Implausible Demand}

Melissa Chandler

Royal Military College of Canada

From shortly before Confederation in 1871 , to the present day, the western population of Canada has felt isolated. The western Canadians feel as though the power holders in Ottawa have too much control. A phenomenon which has led to this feeling of alienation is an Upper House staffed with federal government appointees. When constitutional negotiations were occurring in 1980, the premiers and Prime Minister were discussing what kind of changes should be made to the Constitution. At the time, the premier of Alberta brought up what is now one of, if not the, major issue in the West: Senate reform. This issue has led the West to view Ottawa as having too much power. Furthermore, it has led to the feeling of alienation. This paper will discuss why Senate reform is desirable, but not possible.

To begin, the current division of the Senate will be given, as well as a description of how Alberta ended up with fewer seats. By describing how the Senate is currently divided, one is able to see the significant power and influence that Ontario and Quebec hold over the other provinces in the Upper House. The Senate is divided as such: twenty-four seats for Ontario, twenty-four seats for Quebec, twentyfour seats for western Canada (six seats for Saskatchewan, six for Manitoba, six for Alberta, and six for British Columbia), ten seats for Nova Scotia, ten seats for New Brunswick, four seats for Prince Edward Island, and six seats for Newfoundland and Labrador. In addition, each territory has one seat.

Essentially, Alberta ended up with fewer seats in the Senate due to the fact that it joined thirty-eight years after the conception of the Confederation. More specifically, Alberta joined the Canadian Confederation in 1905. Alberta's physical distance from Ottawa was a major concern of its citizens. Historically, "when one turn[ed] west to the open prairies, the cities and towns fade[d] into the background and life concern[ed] itself with the fortunes of the elements... [Alberta's] greatness rest[ed] on wheat and cattle and all that [was] involved in raising these" (Watson 1965, 28). Although its physical distance from Ottawa has not changed, Alberta is now much more of an asset to the Canadian economy. This province is now counted on for much more than wheat and meat. The biggest item in this case would be Alberta's oil. Alberta's "Oil Sands are the third-largest proven crude oil reserve in the world, next to Saudi Arabia and Venezuela" (Government of Alberta, "Energy: Oil Sands"). Not only does this make Alberta a major contributor economically in Vol. 13 Federalism-E
Canada, but now Alberta has the possibility of becoming a major energy contributor globally. China, in particular, is a major energy consumer who has already showed interest in the Oil Sands.

In 2002, “Alberta [was a] 'have' province... being [one] of the three Canadian provinces whose economic position is sufficiently favourable that [it] does not receive equalization payments from the federal government" (Boychuk \& Vannijnatten 2002, 9). That being said, should Alberta not have a greater voice in the Senate? Ontario, with four times the amount of say in the senate as Alberta, is currently a "have-not" province. Essentially, a poorer province is being given more power at the federal level. Overall, Alberta was late to join the Canada Confederation. As such, its particular influence, or political power, within Canada as a whole is less than Albertans would like. However, Alberta is gaining more influence now than it had in the past (i.e. the beginning of the twentieth century) due to its economic dominance.

In addition to economic dominance, Alberta also wants to dominant more politically. An obvious way to accomplish this would be through Senate reform. Currently, "the Canadian Senate is such a clear exception among federal systems across the world; no other democratic federal state has an upper house staffed by federal government appointees - actually prime ministerial appointees - with no input from the governments or citizens of the provinces they are deemed to represent. (Senators are appointed by the prime minister of the day and serve until age 75)" (Gibbins \& Berdahl, 2003, 191). Evidently, those in the Senate lack much in the way of public credibility. The "Triple E model" dominates Senate reform discussions in the West. The three "E"s in this case stand for: a Senate based on direct popular election, equality of representation for the provinces, and a Senate to exercise effective powers (referring to the fact that the House of Commons is able to override Senate-made decisions) (Gibbins \& Berdahl 2003, 193). Another point in favour of Senate reform would be that it "would provide a check on the power of the Prime Minister and cabinet" (Gibbins \& Berdahl 2003, 193). However, "western Canadian discontent is not sufficient to ignite or drive constitutional change" (Gibbins \& Berdahl 2003, 193) at this point in time.

Furthermore, the "Triple E is all about the foreground; there is no depth to the proposal because there is no depth to the analysis" (Smith 2003, 5). The analysis part that is referred to here is the "theory of practice" should a reform take place. Like many other ideas, they look better on paper than they do in practice. It would be

Page 17 
really hard to introduce the Triple E format. For example, an elected Senate: Canadians of all levels of society go to the polls rather frequently, whether it is for a municipal, provincial, or federal election. Even so, the voter turnout is never overly impressive. It would be difficult to get Canadian citizens to come out to another "kind" of election. People do not always tend to educate themselves on what the election is for and who to vote for. When helping out with the Kingston municipal elections in 2010, I was asked on numerous occasions by voters: "Who should I vote for?" People are ignorant, so why should they be trusted with such an important vote?

The next issue is equality. It has been many years since Confederation and equal representation should, theoretically, be a common trend nowadays. However, the government is still run by human beings. As a species, we are prone to seek whatever will benefit us the most, even if it means that someone around us suffers in comparison. Central Canada was the most powerful at Confederation, so why would it want to be any less powerful today?

The last issue is that regarding an effective Senate. Currently, the Senate does not possess much in the way of power as the House of Commons has the ability to overrule any decision. If this "veto" power were to be taken away, there would obviously be the chance of stalemates occurring. In order to avoid and/or get past this, someone would need to have the last say. But who would get such a say? The Governor General perhaps? Who then, would decide the individual who gets the final say? As author William Thorsell argues, "the next great Canadian cause should be reform of our electoral and parliamentary systems to require much more negotiation among political persuasions and regions through the life of any parliament. Our zero-sum democracy needs to move to a 60-40 democracy, where majorities prevail only after having to respond to other interests and opinions" (Gibbins \& Berdahl 2003, 194). It should also be mentioned that the "Triple E proposal may not be forgotten but interest in it is at best episodic" (Gibbins \& Berdahl 2003, 194). The interests and major concerns of citizens change rather frequently. If Senate reform is to be taken seriously, then the issue has to be the number one concern over a long period of time.

It has already been mentioned that one of the three "E"s stand for the effectiveness of the Senate. It should be pointed out that "until there is agreement on what the Senate is supposed to do, there will be no agreement on its modification" (Smith 2003, 6). The Senate would have to have the same responsibilities as it does now concerning legislation, but be without the worry of its decisions being overruled by the House of Commons. Those within the Senate realize that they do not have the legitimacy that is required to refuse the passage of legislation. If senators were to be elected, then this would not be an issue. If this were not an issue, then it would take even longer to pass pieces of legislation. With respect to the Senate, how much power is too much?

Additionally, more seats for each of the provinces in the West would mean fewer seats, and therefore less power and influence, for the provinces of Ontario and Quebec. Seeing as "Quebec rather than the West drives the process" (Smith 2003, 6) of constitutional change, there is no wonder why Senate reform has yet to occur. Why would Quebec agree to Senate reform? That would mean giving up influence and power within the Senate. The fact that central Canadian provinces have more power than any province in the West further reinforces the West's feelings of alienation and isolation.

Even so, the West has yet to give up on its hope for Senate reform. Not only has "such reform been accomplished by other countries," (Gibbins \& Berdahl 2003, 195 ) it is also believed that there are a number of factors that could lead to the rise of this issue again at the federal level. These factors include: the possibility of the independence movement rising again in Quebec, continental integration, democratic crisis in the Senate, developments with respect to Aboriginal self-government (and territory request for provincial recognition), etc. (Gibbins \& Berdahl 2003, 195).

It is believed by separatists that a separation is needed should Quebec wish to gain full control over the French language and Quebecois culture. The belief that Quebec needs a "third opportunity" is held by many who wish to see an independent Quebec state. Well, what if the population of Quebec says "no" a third time? Are separatist political parties going to want to give Quebec citizens a fourth opportunity? Or possibly a fifth? Let's be realistic here. The reason why the Bloc Quebecois (BQ) was so popular in the federal elections of 2004, 2006, and 2008 is due to the involvement of the Liberal Party of Canada (LPC - Quebec sector) in the Sponsorship Scandal. In 2000, the LPC held 172 seats in the House of Commons. In the 2004, 2006, 2008, and 2011 federal elections, the LPC seat count was 135, 103, seventy-seven, and thirty-four respectively state-wide (Simon Fraser University, "Canadian Election Results" 2000, 2004, 2006, 2008, and 2011). In Quebec, the LPC held thirty-six seats in 2000. In the 2004, 2006, 2008, and 2011 federal elections, the LPC seat count was twenty-one, thirteen, fourteen, and seven respectively (Simon 
Fraser University, "Canadian Election Results" 2000, 2004, 2006, 2008, and 2011). Specifically after the 2004 federal elections (i.e. the height of the Sponsorship Scandal), the BQ recorded a high of fifty-four seats in the province of Quebec. This is the highest number of seats the BQ ever held. (This amount of seats was also seen in 1993).

As these figures demonstrate, support for a separatist political party only went up after the misfortune of another party. Once enough time passes, people will start to forget about the Sponsorship Scandal and people will once again start to support political parties other than the separatist parties. This was seen in the 2011 federal elections. As it has already been mentioned, the BQ only obtained seven seats in the last election. Clearly, citizens of Quebec do not merely vote for a separatist party because they want to separate. Quebecers will vote for whichever party they hate the least.

Yet another way to put Senate reform back on the agenda was discussed in the famous Alberta "firewall" letter, written in 2001 by Stephen Harper, Tom Flanagan, Ted Morton, Rainer Knopff, Andrew Cooks, and Ken Boessenkool. This includes the use of "section 88 of the Supreme Court's decision in the Quebec Secession Reference" (Harper \& al. 2001, 1). This dictates that a "clear majority on a clear question" (Harper \& al. 2001, 1) must be achieved in order to successfully attain a constitutional change. It will be hard to achieve "a clear majority on a clear question," however, seeing as people do not generally like change. A major contributor to this would be the fact that the Canadian public does not possess the knowledge required to fully understand the meaning of "Senate reform." The average citizen today probably could not even describe what the Senate does within the Canadian government and how individuals are selected to be senators. The public does not trust the government, or the politicians within. Many people believe that all politicians "lie, cheat, and steal."

Another way for Senate reform to become a reality would be via a national vote. This implies that the notion of Senate reform would have to be supported by people from across the country. What would be the benefit for citizens in Ontario and Quebec to vote for Senate reform? It is true that all senators would be considered "legitimate," but how could one convince Ontarians and Quebecers that the West gaining more power and influence within the Senate is beneficial for them?

Vol. 13 Federalism-E
Additionally, the West's feelings of alienation and isolation were not addressed in the Meech Lake Accord in 1987. The "accord's omission of Senate reform represented a major concession by Alberta's premier, Don Getty, who had publicly pledged to make Senate reform a condition for accepting Quebec's conditions" (Russell 2004, 137). It is important to note that the Meech Lake Accord did include "an interim amendment that until such time as Senate reform was accomplished, the federal government would appoint senators from lists submitted by the premiers" (Russell 2004, 137). This was added by Prime Minister Brian Mulroney in order to win over Alberta's premier, Getty. Overall, the accord was more aimed towards Quebec-based interests and not western Canadian-based interests. I am referring here to the "distinct society" clause of the Meech Lake Accord. Seeing as this particular accord was defeated in the end, it is evident that the West's concerns were not mended. As such, its feelings of alienation and isolation did not disappear. We would see a similar effect when the Charlottetown Accord in 1992 came and died in a similar fashion. Canadians, specifically western Canadians in this case, are not going to vote in favour of an accord which does not benefit them. Why would the non-Quebec residents vote for an accord which was to benefit Quebec more than them? Why would non-Western Canadian residents vote for an accord that was to benefit the West over them? And why would Western Canadians vote in favour of an accord which did not include the full idea of Senate reform? Answer: they would not.

In addition, numerous meetings have taken place between Ontario and the western provinces. The "main dialectic in these meetings was....a strong desire to curb central Canada's power in Ottawa" (Russell 2004, 196). As can be seen, it is the provinces with the most seats in the Senate which hold the most power in Canada: Ontario and Quebec. Senate reform is of symbolic significance. For the political elites in western Canada, Senate reform stands "for a restructuring of the federation to overcome the perceived domination of national affairs by central Canada" (Russell 2004, 205). Western Canada may want to take some of the power that central Canada currently holds, but central Canada is not going to give up even a fraction of its power and influence without a fight.

Other reasons which support why Senate reform is simply not possible include: (a) reforms can have contradicting effects depending on which role is being evaluated, (b) the current amending formula which requires a majority of the population and a majority of the provinces to amend the Senate's powers and the method of selection of its members, (c) the restrictive influence of the House of 
Commons (Smith 2003, 4). With regards to the first argument (reforms can have contradicting effects depending on which role is being evaluated), it should be noted that western Canadians are concerned with the role of representation. Currently, the West is significantly outnumbered by central Canada with respect to population size. A reform, should one ever occur, would have to proceed with this in mind. But how would the West convince the rest of Canada that a reorganization of the Senate was desirable?

Concerning the second argument (the current amending formula which requires a majority of the population and a majority of the provinces to amend the Senate's powers and the method of selection of its members), this is referring to the need for a "clear majority on a clear question." The question is: "Should the Senate represent the provinces proportionally with regards to population and geographic size?" A clear majority would be hard to obtain considering that western Canadians are virtually the only ones interested in obtaining more seats in the Senate. One could consider the Territories, which are in search of provincial status, as being interested in Senate reform as well. But what about the rest of Canada? Are the Maritimes interested in Senate reform? Seeing as the Eastern provinces currently have thirty seats in the Senate (compared to the twenty-four West seats), it is doubtful that they would want the West to gain just as much, if not more, power than themselves.

Regarding the third reason (the restrictive influence of the House of Commons), how would proper representation benefit the country if the Senate still had little power over the Lower House? The power, or lack thereof, possessed by the Senate is an issue. As of now it seems as though it has none. Its powers need to be increased to a point where it has some kind of "real" authority. But what if the Senate were to obtain this "real" authority and have more power over the Lower House? This power in conjunction with legitimacy (from being elected) could lead to an Upper House with far too much control in relation to the Lower House.

There is a way, however, by which Senate reform could be slowly introduced. As it was pointed out earlier, current Prime Minister Stephen Harper was a co-author of the famous Alberta "firewall" letter. This dictates that Harper, from a Calgary (i.e. western Canadian) constituency, is a strong advocate of Senate reform. In June 2011, the Harper government induced the Senate Reform Act with the purpose of making "the Senate more democratic, accountable, and representative of Canadians" (Government of Canada: Democratic Reform, "Harper Government Introduces the Senate Reform Act"). The Senate Reform Act, introduced by the House of Commons, "provides a voluntary framework for provinces to implement a democratic process that enables voters to select nominees for the Senate. The Prime Minister will be required to consider the names of Senate nominees when making recommendations on appointments to the Senate" (Government of Canada: Democratic Reform, "Harper Government Introduces the Senate Reform Act"). Although this initiative was a positive step in the direction of Senate reform, it is not binding. One should take note of words like "voluntary" and "consider." This Act provides that provinces should implement a process by which to nominate individuals to be senators. Furthermore, this Act requires that the Prime Minister needs to consider the names of Senate nominees, but not necessarily choose a particular individual from this list.

Many scholars believe "there is a practical need to do something in order to enhance the upper house and thereby make it a constructive element of Parliament within current constitutional arrangements" (Smith 2003, 4). As this paper is arguing, Senate reform is desirable, but not possible within the foreseeable future. Senate reform is desirable as elected senators would be considered more legitimate, equal representation would mean fairness for all provinces, and an effective Senate would be more beneficial with regards to the legitimacy of the Government of Canada. It is clear that something must be done to extinguish the feeling of alienation in western Canada, or it is possible that we will end up with the same separatist feelings that are still present in Quebec. But Senate reform is not possible for the moment seeing as all citizens across the country would have to be in accordance. What is the benefit for those in Central Canada to have fewer seats in the Senate? How would one convince the ill-informed Canadian public that this change would be a good idea? Would a vote for Senate reform spur another vote for Quebec sovereignty? These are just a few of the reasons why Senate reform is not going to occur any time soon via a popular vote (i.e. a referendum). 


\section{Bibliography}

Boychuk, Gerard W., and Debora L. Vannijnatten. "The Canadian "West" as a Public Policy Space?: Public Policies in Western Canadian Provinces from a National and Cross-National Perspective." BC Studies. no. 133 (2002): 530.

Gibbins, Roger and Loleen Berdahl. 2003. Western Visions, Western Futures: Perspectives on the West in Canada, Second Edition. Peterborough: Broadview Press, pp. 191-201.

Government of Alberta, "Energy: Oil Sands." Accessed March 11, 2012. http://www.energy. alberta.ca/oilsands/oilsands.asp.

Government of Canada: Democratic Reform, "Harper Government Introduces the Senate Reform Act." Last modified June 21, 2011. Accessed April 7.

2012.http://www.democraticreform.gc.ca/index.asp?lang=eng\&page=newscomm\&doc=news-comm/20110621.

Harper, Stephen, Tom Flanagan, Ted Morton, Rainer Knopf, Andrew Crooks, Ken Boessenkool. 2001. "An Open Letter to Ralph Klein" (The Alberta Firewall Letter), National Post 24 January.

Russell, Peter H.. Constitutional Odyssey: Can Canadians Become a Sovereign People?. 3 ed. Toronto: University of Toronto Press, 2004.

Simon Fraser University, "Canadian Election 2000 Results ." Accessed April 7, 2012. http://www.sfu.ca/ aheard/elections/2000-results.html.

Simon Fraser University, "2004 Canadian Election Results." Accessed April 7, 2012. http://www.sfu.ca/ aheard/elections/2004-results.html.

Simon Fraser University, "2006 Canadian Election Results." Accessed April 7, 2012. http://www.sfu.ca/ aheard/elections/2006-results.html.

Simon Fraser University, "2008 Canadian Election Results \& 2011 Canadian Election Results." Accessed April 7, 2012.

http://www.sfu.ca/ aheard/elections/results.html. Press, pp.149-175.

Vol. 13 Federalism-E

\section{Smith, David E. 2003. "The Canadian Senate: What is to be Done?," In The
Canadian Senate in Bicameral Perspective. Toronto: University of Toronto \\ Smith, David E. 2003. "The Canadian Senate: What is to be Done?," In The
Canadian Senate in Bicameral Perspective. Toronto: University of Toronto}

Watson, J. Wreford. "Canadian Regionalism in Life and Letters." The Geographical Journal. 131. no. 1 (1965): 21-33. 